\title{
Rhetorical and Postcolonial Readings of John 4 and 8: Its Hermeneutical Application in Korea ${ }^{1}$
}

\author{
KWON Oh-Young \\ Alphacrucis College, Sydney, Australia
}

\begin{abstract}
This article explores rhetorical and postcolonial readings of John 4 and 8 . These Johannine chapters contain rhetorical characteristics and the rhetorical technique of "comparison" that is implicitly indicated in John 4:3-9 and 8:48-58. These approaches suggest that the Johannine author deliberately employed them in order to present Jesus as Christ/Messiah who embraced nationsJews, Samaritans, and all Gentile nations, just as Abraham is seen as the father of all nations. Rhetorical and postcolonial readings further highlight Jesus's messianic act of passing through Samaria, which challenged and decolonized the Jews' (pre)dominant claim of their religious and ethnic superiority over Samaritans under the colonization of the Roman Empire and the hegemony of Roman imperialism. Furthermore, the highlight is reread and re-evaluated for Koreans in the Korean peninsula, which is in a difficult political and diplomatic position that requires reconciliation and reunification between the two Koreas. All these hermeneutical attempts and outcomes encourage and motivate one to go beyond religious and ritual readings of the Gospel of John and place more emphasis on political and ideological readings of Jesus's interactions with Samaritans and Jews in the gospel.
\end{abstract}

\section{Keywords}

rhetorical, postcolonial, messianic act, reunification, Korean peninsula

1 This essay is a revision of the paper that I read at the 2017 SBL International meeting in Berlin, Germany. My appreciation goes to my Alphacrucis colleague U-Wen Low for his useful comments and scholarship on postcolonial readings of the NT (see U-Wen Low, "Towards a Pentecostal, Postcolonial Reading of the New Testament," Journal of Pentecostal Theology 29 [2020]: 229-243). 


\section{INTRODUCTION}

This article explores rhetorical and postcolonial readings of John 4 and 8 that address Jesus's interactions with Samaritans in Sychar, a Samaritan city, and with Jewish religious leaders in Jerusalem, the center of the Jewish religion. ${ }^{2}$ The Johannine texts contain indicators of the author's rhetorical strategy and rhetorical characteristics and particularly the rhetorical technique of comparison that was precisely explained in Greco-Roman rhetorical handbooks such as Aristotle's Rhetoric, Cicero's Topica, and Quintilian's Institutio Oratoria (see below).

The rhetorical indicators and features implicitly exhibited in the Johannine passages are as follows: "He/Jesus had to go through Samaria" (4:4); "For Jews have no dealings with Samaritans" (4:9); and "Are we/Jews right in saying that you/Jesus are a Samaritan and have a demon?" (8:48b). ${ }^{3}$ Moreover, the rhetorical technique of comparison is vividly and explicitly displayed in the Johannine arrangement of different words in a comparative sense: Samaria and Judea in John 4:3-4; Samaritans and Jews in John 8:48; Jesus and Jacob in John 4:5, 12; and Jesus and Abraham in John 8:53, 57, 58.

This essay argues that such distinctive rhetorical characteristics highlight two important points: One is that the Johannine author deliberately employed such rhetorical features in John 4 and 8 , in which he presented Jesus as the Christ who fulfilled the covenants that God made with Jacob (Gn 35:10-12) and Abraham (Gn 17:4-7) in order to show that Jesus was Christ/Messiah who treated all nations and all peoples equally. Thus, peoples' racial and ethnic distinctions bothered him by any means (Jn 4.9; 8.48).

On the other hand, Jesus's act of passing through Samaria from Judea and Jerusalem (4:3-4) demonstrates a significant element of the messianic mission that Jesus did overcome and transcend the religious, ethnic, and ideological boundaries drawn between Jews and Samaritans in Palestine. His act deliberately challenged the Jews' racial egoism and nationalism

2 For postcolonial readings of John's gospel, see Musa W. Dube and Jeffrey L. Staley, eds., John and Postcolonialism: Travel, Space and Power (London and NY: Sheffield Academic Press, 2002), 1-224; Fernando F. Segovia, "The Gospel of John," in A Postcolonial Commentary on the New Testament Writings, ed. Fernando F. Segovia and R.S. Sugirtharajah (London: T \& T Clark, 2009), 156-193. But these studies do not involve rhetorical interpretations.

3 All scriptural quotes are from the New Revised Standard Version. 
and was intended to decolonize the (pre)dominant claim of the Jews over the Samaritans under Roman colonization and imperialism, which was characterized by imperial cults that venerated Roman emperors and the imperial family (see below). To support these arguments, a brief exegesis of the word dei in John 4:4 is required.

\section{A Brief Exegesis of DEI IN JoHn 4.4}

Edei de auton dierchesthai dia tês Samareias (It was a divine necessity and mission that he/Jesus had to go through Samaria; my translation).

In the literary segment of John 4:1-6, verse 4 appears to be mentioned in passing and not to have noteworthy theological implications or literary distinction. ${ }^{4}$ Hence, readers tend to overlook verses 3 and 4 and go directly to verse 5, which begins the narrative of Jesus's arriving in Sychar and there encountered a local Samaritan woman at the well of Jacob. ${ }^{5}$

The first Greek word edei in John 4:4 is the third-person singular imperfect active indicative form of dei. ${ }^{6}$ It is translated "must," "ought to," "have to," or "should" (especially NRSV). ${ }^{7}$ The auxiliary verb functions to support a main verb following and to support and emphasize the meaning of the main verb.

The word refers to something that absolutely must happen. J. Eugene Botha notes that the word denotes something that must be done as "a result

4 J. Eugene Botha reads John 4:1-42 from speech-act theory and thoroughly examines and exegetes the episode of Jesus who interacted with the Samaritan woman in the Johannine text and especially verses 1-9 (J. Eugene Botha, Jesus \& $\sigma$ the Samaritan Woman: A Speech Act Reading of John 4:1-42 [Leiden, New York, and Cologne: Brill, 1991], 96-122). He investigates this episode in terms of the Jew-Samaritan controversy and the hostile situation. Yet he pays little attention to Jesus's journey to Samaria in verse 4 and describes him as a Jewish rabbi rather than as Messiah (see Botha, Jesus \& the Samaritan Woman, 103).

5 The words "Samaria" and "Samaritan" occur more frequently in the Gospel of John (nine times: 4:4, 5, 7, 39, 40; 8:48) than in the Synoptic Gospels (Mt 10:5; Lk 9:52; $10: 33 ; 17: 11,16)$.

6 The Greek word dei occurs 101 times in the New Testament (e.g., Mt 16:21; Mk 8:31; Lk 4:43; Acts 3:21; Rm 8:26; 1 Cor 15:53; 2 Cor 11:30; 1 Tm 3:7; Heb 2:1; Rv 22:6); the word occurs ten times in the Gospel of John: 3:7, 14, 30; 4:4, 20, 24; 9:4; 10:6; 12:34; 20:9.

7 Walter Bauer and Frederick William Daker, rev. and ed., Greek-English Lexicon of the New Testament and other Early Christian Literature, $3^{\text {rd }}$ ed. (BDAG) (Chicago and London: University of Chicago Press, 2000), 213-214. 
of compulsion, whether internal—as a matter of duty—or external-law,

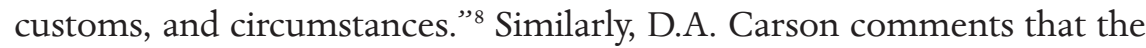
word dei is employed to highlight "the compulsion of divine appointment." Brendan Byrne further claims that the "divine necessity" of Jesus's act drove "his mission beyond Israel" and the Jewish people. ${ }^{10}$

It can be argued, therefore, that the Johannine author uses dei in John 4:4 to emphasize that Jesus's going through Samaria was his mandatory act as Messiah. Furthermore, this notion is, to some extent, supported by the Johannine description in its preceding verses (vv. 1-3), which implicitly indicate that Jesus had to leave Judea. He appears to have noticed his growing "popularity" and "influence" among the locals over the Pharisees in the region of Judea (Jn 4:1). ${ }^{11}$ The phenomenon of his increasing (religious and political) popularity seems to have caused the Pharisees to be unfriendly, vigilant, and cautious toward Jesus (Jn 7:1). These attitudes would later develop into conflict and hostility against him, which is demonstrated in John 7:32-48; 8:1-59. Yet Jesus seems to have avoided the trouble by leaving Judea for Galilee, his homeplace. ${ }^{12}$

Clearly, verse 4 was not mentioned in passing. The Johannine author, rather, uses a rhetorical strategy to show that Jesus's act was inevitable and necessary to fulfill his mission as Messiah in Samaria for Samaritans. He broke down the religious, ideological, and ethnic divides between his fellow Jews and other Gentiles and Samaritans in Palestine and welcomed all nations and all peoples in the hospitality of God and his kingdom/ empire (Jn 4:7-15, 39-43).

If the author arranges the verse for rhetorical purposes, we should pay attention to it. The word dei endorses Jesus's messianic mission in Samaria by showing him intentionally fraternizing with the local inhabitants whom the Jews denounced and rejected (Jn 4:9). This notion will be affirmed in the following rhetorical and postcolonial readings of John 4 and 8.

8 Botha, Jesus \& the Samaritan Woman, 103.

9 D.A. Carson, The Gospel According to John (Grand Rapids: Eerdmans; Leicester: Apollos, 1991), 216.

10 Brendan Byrne, Life Abounding: A Reading of John's Gospel (Strathfield: St Paul, 2014), 81; also Gine and Cherian, "John," 1398.

11 Carson, John, 215.

12 See Byrne, Life Abounding, 80; Colin G. Kruse, TNTC: John (Nottingham: IVP, 2003), 128. 


\section{Rhetorical and Postcolonial READINGS}

This essay advocates a collective biblical hermeneutical methodology of rhetorical and postcolonial readings that, with help of Greco-Roman rhetorical handbooks (see below), explores rhetorical characteristics that a biblical text implicitly contains, and the author's rhetorical strategies, intents, and plots deliberately and consciously hidden behind the biblical text. The author effectively presents these rhetorical tools and strategies that encourage and attract the attention of his readers (readers-oriented reading) and that help persuade, stimulate, and challenge his readers and audience to appreciate, accommodate, and put into practice his arguments, messages, and theological implications. ${ }^{13}$

On the other hand, postcolonial readings disclose that a biblical text contains hierarchical power structures and concepts of imperialism and colonization in the religious, social, political, economic, ideological, cultural, and linguistic dimensions. Postcolonial approaches attempt to decolonize interpretative and hermeneutical outcomes and indicators and the theological insights of the biblical text that are taken from within the framework of imperialism, colonization, and elitism and from the hierarchical, political, ideological, and imperial perspectives of people in power, such as emperors, colonizers, rulers, or dictators. ${ }^{14}$

13 For rhetorical readings of John's gospel see Gerard van den Heever, "Finding Data in Unexpected Places (or: From Text Linguistics to Socio-Rhetoric): Toward a SocioRhetorical Reading of John’s Gospel," Neotestamentica 33, no. 2 (1999): 343-364; cf. C. Clifton Black, "Rhetorical Criticism" in Joel B. Green, ed., Hearing the New Testament: Strategies for Interpretation, $2^{\text {nd }}$ ed. (Grand Rapids: Eerdmans, 2010), 166-188, esp. 179-180 for a rhetorical interpretation of John 4:7-42; W. Randolph Tate, Biblical Interpretation: An Integrated Approach, $3^{\text {rd }}$ ed. (Peabody: Hendrickson, 2008), 286-288; also Oh-Young Kwon, 1 Corinthians 1-4: Reconstructing its Social and Rhetorical Situation and Re-reading It Cross-Culturally for Korean-Confucian Christians Today (Eugene: Wipf and Stock, 2010), 2-11, 60-78, 133-150.

14 See Jeremy Punt, "(Southern) African Postcolonial Biblical Interpretation: A White African Perspective," Journal of Early Christian History 7 (2018): 1-21; Musa W. Dube, Andrew M. Mbuvi, and Dora R. Mbuwayesango, eds., Postcolonial Perspectives in African Biblical Interpretations (Atlanta: Society of Biblical Literature, 2012), 1-26; Fernando Segovia, "Postcolonialism and Comparative Analysis in Biblical Studies," Biblical Interpretation 7 (1999): 192-196; Stephen D. Moore and Fernando F. Segovia, eds., Postcolonial Biblical Criticism: Interdisciplinary Interpretations (London: T\&T Clark, 2006), 32-120; Tate, Biblical Interpretation, 312-317. 
The Gospel of John contains distinctive characteristics and indicators that signify its colonial and imperial context. In Jesus's time, the province of Judea to which both Samaria and Judea belonged was under Roman rule (see Jn 18:28-19:27; cf. Lk 3:1). ${ }^{15}$ In the gospel, nevertheless, Jesus appears not to challenge or subvert the Roman authorities in Palestine. This is explicitly demonstrated in the Johannine expressions: "I/Pilate find no crime in him/Jesus" (Jn 19:4, 6; cf. Lk 23:4); "Pilate sought to release him/ Jesus" (Jn 19:12). But Jesus does not seem to have submitted to Roman authorities either (see Jn 19:11).

The gospel seems to present a picture of friendly relationships with the Roman authorities. For instance, in John 4:46-54, Jesus heals the son of a royal official (basilikos). The official and all his household believe in him and come under the hospitality of God (Jn 4:53).

Nevertheless, as we read the Fourth Gospel from rhetorical and postcolonial perspectives, a good number of passages are found that contain distinctive elements and expressions that call for a postcolonial reading. For instance, in John 3:3, 5; 18:36 the phrases "the empire of God" (he basileia tou theou) or "my/Jesus's empire" (he basileia mou) ${ }^{16}$ could indicate that the author deliberately presented the empire of God as opposed to the empire of Caesar that persecuted the Johannine communities who were identified with the characters who claimed Jesus as king (basileus) (Jn 1:49; $6: 15 ; 12: 13,15 ; 16: 33$; cf. 18:33, 37, 39; 19:3, 12, 14, 15, 19, 21). Further, it would be the author's rhetorical strategy hidden behind Jesus's words in John 18:36 to encourage his readers to acknowledge and appreciate their belongingness not to the empire of Caesar (kaisar) (Jn 19.12, 15) ${ }^{17}$ but to the empire of God (theos) where Jesus is the king (basileus) who welcomes them and provides hospitality (Jn $3: 16 ; 15: 19 ; 18: 36){ }^{18}$

15 For Roman imperialism and imperial cults in Judea in the time of Jesus see Joan E. Taylor, "Pontius Pilate and the Imperial Cult in Roman Judaea," New Testament Studies 52 (2006): 552-582.

16 The Greek word basileia is translated as "empire" in this essay.

17 In the Synoptic Gospels the word "Caesar" (kaisar) does not occur in the section of Jesus's trial before Pilate (see Mt 27:1-26; Mk 15:1-15; Lk 23:1-25).

18 The phrase "the kingdom/empire of God" appears more frequently in the Synoptic Gospels than in John: Matthew's Gospel uses its equivalent "the kingdom/empire of heaven" (he basileia tōn ouranōn) in 3:2; 4:17, 23; 5:3, 10, 19, 20; 6:10, 33; 7:21; 8:11, 12; $9: 35 ; 10: 7 ; 11: 11,12 ; 12: 28 ; 13: 11,19,24,31,33,38,41,43,44,45,47,52 ; 16: 19,28$; 
Furthermore, the Johannine author frequently employs the phrase "Son of God" (ho huios tou theou, Jn 1:34, 49; 3:18; 5:25; 10:36; 11:4, 27; 19:7; 20:31; cf. 3:16, 17; 5:19, 20; 17:1), and the phrase "Son of Man" (ho huios tou anthrōpou, Jn 1:51; 3:13, 14; 5:27; 6:27, 53, 62; 8:28; 9:35; 12:23, 34 [twice]; 13:31). These two expressions clearly refer to Jesus and represent the sonship of Jesus as divine and human. The Johannine Gospel further affirms Jesus as Christ/Messiah or Savior of the world (ho sōtēr tou kosmou) (Jn 4:42; cf. 3:16-17). These are titles claimed by the Roman emperors as well. The emperors were venerated as deities, and the imperial family was promoted to divine status in the imperial cult and at sites of emperor worship. ${ }^{19}$

Using the titles "Son of God" and "Son of Man" for Jesus in his rhetorical plot, the author of the gospel deliberately presents him as the God and Christ/Savior whom his Johannine community continued to confess and worship rather than the emperor, whom they were forced to honor as god. He then challenges and motivates them to identify with the biblical characters who boldly confess Jesus as Son of God and Messiah/ Savior in the predominant religious context of Judaism in Palestine under Rome (Jn 1:49; 11:.27; 18:28-19:24). And his readers were encouraged to acknowledge that Jesus, not the emperor, was the source of their life and salvation (Jn 3:16-17; 14:6). Furthermore, his rhetorical strategy hidden behind the use of these titles was an implicit challenge to the Roman Empire, its imperial system, and the emperor that collectively persecuted the Johannine communities (thlipsis, Jn 16:33) who declared the divinity of Jesus Christ and his lordship (kyrios) over them and expressed their loyalty

$18: 1,3$, 4, 23; 19:12, 14, 23, 24; 20:1, 21, 31, 43; 22:2, 13; 24:14; 25:1, 34; 26:29.

Mark's Gospel has the phrase "the kingdom/empire of God" (he basileia tou theou) in $1: 15 ; 4: 11,26,30 ; 9: 1,47 ; 10: 14,15 ; 10: 23,24,25 ; 11: 10 ; 12: 34 ; 14: 25 ; 15: 43$.

Luke's Gospel employs "the kingdom/empire of God" in 4:43;6:20; 7:28; 8:1, 10; $9: 2,11,27,60,62 ; 10: 9,11 ; 11: 2,20 ; 12: 31,32 ; 13: 18,20,28,29 ; 14: 15 ; 16: 16 ; 17: 20,21$; $18: 16,17,24,25,29 ; 19: 11 ; 21: 31 ; 22: 16,18,29,30 ; 23: 42,51$.

19 See Kwon, 1 Corinthians 1-4, 103; Lance Byron Richey, Roman Imperial Ideology and the Gospel of John, CBQMS 43 (Washington, DC: Catholic Biblical Association of America, 2007), 25-178; Allen Brent, "Luke-Acts and the Imperial Cults in Asia Minor,” Journal of Theological Studies 48 (1997): 411-438; Nelson Kraybill, Imperial Cult and Commerce in John's Apocalypse, JSNTSup 132 (Sheffield: Sheffield Academic Press, 1996), 10-235. 
and commitment to him rather than to the emperor (Jn 6:68; 9:38; 13:13, 37).

The majority of scholars contend that the gospel was composed for the Christ-believing community in Ephesus, a part of Asia Minor, during the reign of the tyrant emperor Domitian (81-96 CE) ${ }^{20}$ The Johannine community would have consisted of (diaspora) Jewish Christians and some of Gentile background who may have once belonged to Judaism and the synagogues. These Gentile members can be identified with the Greeks (hellēn) in John 7:35; 12:20-21. ${ }^{21}$ Yet both Jewish and Gentile members would have been expelled from the synagogues because they confessed and believed in Jesus as Christ/Messiah (christos) (see Jn 1:41; 4:29; 7:26; $10: 24 ; 20: 31)$. They can be identified with the characters in John 9:22; 12:42; 16:2 in which the Greek word aposynagogos ("put out of and expelled from a synagogue") occurs, whereas the word appears nowhere else in the entire New Testament. ${ }^{22}$

The members of the Johannine community would have confronted two external hardships and pressures. One was excommunication. They were excommunicated and socially disconnected from the Jewish communities and synagogues that were their religious and cultural centers (see Jn 9:22; 12:42; 16:2). The other one was persecution. The Roman Empire's Christian persecution was extremely severe during the reign of Domitian, who was seen as the tyrant emperor Nero returned from the dead and "who used worship of the image of the emperor as a litmus test of loyalty" to himself and the imperial family (Jn 16:33). ${ }^{23}$ Christianity was treated as

20 Carson, John, 83; Byrne, Life Abounding, 7; Kruse, John, 32; Ben Witherington III, New Testament History: A Narrative Account (Grand Rapids: Baker Academic, 2001), 396-398; Prataq C. Gine and Jacob Cherian, “John,” in Brian Wintle, gen. ed., South Asia Bible Commentary: A One-Volume Commentary on the Whole Bible (Grand Rapids: Zondervan, 2011), 1386-1448, esp. 1386.

21 I am aware that Jason J. Ripley examines John 8 in the framework of Jewish religious ideologies and Roman imperialism (see Jason J. Ripley, "Killing as Piety? Exploring Ideological Contexts Shaping the Gospel of John," Journal of Biblical Literature 134 [2015]: 605-635). In addition, scholars examine the Gospel of John in close relation to Judaism (see Adele Reinhartz, "Judaism in the Gospel of John," Interpretation 63 [2009], 382-393; Cast Out of the Covenant: Jews and Anti-Judaism in the Gospel of John [Lanham: Lexington Books; Fortress Academic, 2018]; J. Andrew Doole, “To Be 'An Out-of-the Synagoguer,"' Journal of the Study of the New Testament 43 [2021]: 389-410).

22 See Doole, “'An Out-of-the Synagoguer,” 389-390; Gine and Cherian, “John,” 1386.

Witherington, New Testament History, 397. For the study of John's Gospel in relation 
an illegal religion in the Roman Empire because it refused to worship the traditional Roman gods such as Jupiter, Juno, Venus, Apollo, and Minerva. ${ }^{24}$ More critically, the Christians abandoned the veneration and worship of the emperor at imperial cults that were reinforced by Domitian and that took place in Asia Minor, including Ephesus. ${ }^{25}$

To sum up, all these descriptions as a unit contribute to the characterization of the Roman imperial and colonial context of the Gospel of John and to the legitimation of postcolonial and rhetorical approaches for the interpretation of the Johannine Gospel.

\section{Rhetorical and Postcolonial READINGS OF JOHN 4 AND 8}

Rhetorical and postcolonial methodologies motivate one to pay attention to the Johannine description of Jesus's act of going through Samaria in John 4.4 and to the Johannine demonstration of Jesus's attitude toward his opponents who were mostly the Jewish religious leadersPharisees and scribes-who were observant Jews and Torah-keepers in John 8:48-49 (also Jn 8:3, 13). ${ }^{26}$

These Jewish leaders asked him a cunning question (Jn 8:48): "Are we not right in saying that you are a Samaritan and have a demon?" Astonishingly, Jesus appears to have refused consciously to answer their question. He ignored the first part of the question (is he a Samaritan?), while he answered the other one (does he have a demon?) in 8:49. ${ }^{27}$ What,

to its Roman imperial context see Richey, Roman Imperial Ideology, 15-192; Jason J. Ripley, “'Behold the Man'? Subverting Imperial Masculinity in the Gospel of John,” $J$ Bible Recept 2 (2015): 219-239.

24 Kenneth L. Waters, Sr., "Empire and the Johannine Epistles," Review and Expositor 114 (2017): 542-557, esp. 556; Witherington, New Testament History, 394.

25 See Allen Brent, "Luke-Acts and the Imperial Cults in Asia Minor," Journal of Theological Studies 48 (1997): 411-438, esp. 412.

26 For an examination of Jesus's opponents in John's Gospel see Kai Akagi, "The Light from Galilee: The Narrative Function of Isaiah 8:23-9:6 in John 8:12," Novum Testamentum 58 (2016): 380-393, esp. 389-393.

27 If he was demon-possessed, he would not have the characteristics of the Christ/ Messiah who extends the hospitality of God, warm welcome, and forgiveness to everyone, including Jewish religious leaders and Roman officials who crucified him (see Jn 18:1-11; 19:1-37; cf. Lk 21:32-38). Moreover, he did not blame or condemn the woman caught in adultery. Jesus, rather, forgave and accommodated her and invited 
then, is the author's rhetorical intent hidden behind this depiction? This will be dealt with from the rhetorical viewpoint in the following section.

\section{Rhetorical Readings}

In John 4:3-9 the author seems intentionally to place Samaria and Judea, and Samaritans and Judeans (or Jews), side by side for rhetorical effect. His rhetorical strategy is demonstrated in John 4:12, in which a Samaritan woman compares Jesus to Jacob (v. 12, "Are you/Jesus greater than our ancestor/father Jacob?"). Further, in John 8:48-58 the author cleverly positions Jesus before Abraham in the rhetorical sense of comparison (v. 53, "Are you/Jesus greater than our ancestor/father Abraham?"). ${ }^{28}$

\section{The Rhetorical Technique of Comparison}

It is noteworthy that such a rhetorical and intentional arrangement of sets of different words is found nowhere in the other three gospels (see Matthew, Mark, and Luke; cf. Lk 17:11). This rhetorical arrangement is a unique and significant feature of the Johannine Gospel. The author has rhetorically and strategically organized the package of different words by way of comparison. This is a rhetorical technique elucidated in GrecoRoman rhetorical handbooks and writings of Aristotle, Cicero, and Quintilian. ${ }^{29}$ Aristotle explains the technique in his Rhetoric.

Let one thing, then, be said to exceed another, when it is as great and something more-and to be exceeded when it is contained in the other. "Greater" and "more" always imply a comparison with less; "great" and "small," "much" and "little" are a set of words employed in comparison; the "great" is that which exceeds, and that which falls short of it is "small"; and similarly "much" and "little."

In the Greco-Roman rhetorical handbooks the rhetorical technique of comparison was precisely addressed. Writers and speakers or orators would

her into the generosity, hospitality and welcoming of God (Jn 8:1-11).

28 This will be examined below.

29 See Samuel McCormick, "Argument by Comparison; An Ancient Typology," Rhetorica: A Journal of the History of Rhetoric 32 (2014): 148-164.

30 Aristotle, Rhetoric, 1.7.1-3; also Cicero, Topica, 69, 71; Quintilian, Institutio Oratoria, 9.2.100. (Italics are mine.) 
have employed this rhetorical technique in their writings and speeches in order to persuade their readers and audience. The Johannine author would have used this rhetorical method in his gospel and particularly in John 4:3-9 and 8:48-58, wherein he rhetorically refers to two places (Judea and Samaria), two ethnic groups (Samaritans and Jews), and two pairs of names: Jesus and Jacob (4:12) and Jesus and Abraham (8:53). These names of people, places, and ethnicities are deliberately arranged side by side or one after another for rhetorical effect.

In John 4:3-9, according to his rhetorical ploys and objectives, the Johannine author depicts Jesus's journey from Jerusalem (Jn 2:13) and Judea (Jn $2: 23 ; 3: 22$ ), that is, from the center of the Jewish religion, through Samaria, an "unclean" territory, to Galilee, where Nazareth, his home village, was located. ${ }^{31}$ The geographical relocation of Jesus represents the dynamics of his messianic mission that was to challenge and break through the boundaries and divisions between Judea and Samaria and between Jews and Samaritans and other Gentile nations in Palestine. These territories were not simply divided by geographical locations; it is more likely that the divides articulated the religious, ethnic/ racial, and ideological separations under the supreme colonial power of Rome.

Jesus's act of walking across the territorial boundaries (Jn 4:3-5) and his act of interacting with the Samaritan woman in Sychar apparently demonstrate that his messianic mission transcends ethnic, religious, and ideological borders. That Jesus appears to have intentionally asked the Samaritan woman for a drink characterizes his messianic commitment to extending hospitality to other peoples and nations into the kingdom/ empire of God (Jn 3:3, 5; 4:9, 25; 18:36).

Jesus as Messiah/Christ had to pass through Samaria in order to bring both parties together under the love and embrace of God rather than under the colonizing power of the Roman Empire. His act symbolizes God's equal treatment of all peoples and all nations. Further, his act challenged and decolonized the Jewish (pre)dominant claim of their religious, ethnic, ideological, and political superiority over those of the Samaritans and Gentile nations.

31 See Warren Carter, John and Empire: Initial Explorations (New York and London: T \& T Clark, 2008), 161. 


\section{Jesus as Christ of the Nations}

For what purposes does the Johannine author deliberately include such critical tensions between Samaritans and Jews in his gospel?

In John 4 and 8 the author appears to present Jesus as Messiah/Christ (Jn 4:25, 29; 8:12,28) and as a figure who welcomes others and identifies himself with all people of all cultural and ethnic/racial backgrounds. Yet, Jesus seems not to belong or adhere to any particular ethnicity. This is because John's gospel clearly demonstrates the origin of Jesus who was not born of human agent, nor was he identified with one specific culture and ethnicity. Jesus is the Word (ho logos) who existed with God from the beginning of the universe (ho kosmos) and got involved in God's creation ("All things came into being through him, and without him not one thing came into being," Jn 1:1-3). Hence, his birth and the earthly life are presented as shrouded in ambiguity, uncertainty, and speculation (Jn 1:10; 18:37).

Moreover, in the Fourth Gospel Jesus is nowhere introduced and identified as a Jew by birth but by the name of his hometown, Nazareth (Nazôraios, Jn 18:5, 7; 19:19). This is a distinctive feature of the Johannine Gospel as compared to the Gospel of Matthew and the Gospel of Luke, both of which have the birth narrative of Jesus and his Jewish genealogy (Mt 1:1-2.6; Lk 2:1-20; 3:23-38). ${ }^{32}$ Yet Jesus was addressed as a Jew (Ioudaios) by the Samaritan woman (Jn 4:9); as the King of Israel (ho basileus tou Israel) by Nathanael, who was a Jew (Jn 1:49); and as the King of the Jews (ho basileus tōn Ioudaiōn) by Pilate, a Roman governor, and Roman soldiers (Jn 18:33, 39; 19:3, 19, 21 [twice]). The Jewish religious leaders, however, appeared not to have agreed with the title Pilate used for Jesus (Jn 19:21).

The Johannine author ironically had Jesus answer the question of his opponents when he was asked: "Are we [Jewish religious leaders] not right in saying that you are a Samaritan and have a demon?" (Jn 8:48). Jesus did not voice his objection to the first part of the question. He ignored it but explicitly objected to the other part ("I/Jesus have not a demon," v. 49).

Based on the foregoing, therefore, it can be proposed that Jesus may have intentionally refused to be treated as a Jew by his Jewish contemporaries in

32 But it is noticed that the Gospel of Mark has no accounts of Jesus's birth and genealogy, and it begins with the ministry of John the Baptist preaching in the wilderness (Mk 1:2-8). 
terms of ethnicity and racial origin. He may even have obliquely agreed with his opponents when they called him a Samaritan. Thus, the Johannine author portrays Jesus as Christ/Messiah of all peoples and nations including Jews and Samaritans, just as Abraham was the father of all nations (see Jn 8:36-58; Gn 17:4-7). Jesus may have preferred not to be identified with a particular ethnic group. But the Jewish religious leaders regarded him as a Samaritan because he fraternized with the despised Samaritans (Jn 4:4-42).

Jesus's inclusive attitude towards all exhibits his universal messianic mission. He is not only for the Jews as the chosen people of God but also for the Samaritans and for all Gentile and pagan nations whom God made in his image (see Gn 1:27; Is 53:1-12; Jn 20:31). That Jesus was geographically journeying and walking from Jerusalem and Judea through Samaria to Galilee represents him as Messiah/Christ who breaks down and transcends all kinds of divides and boundaries established by peoples and nations due to their differences of religion, ethnicity, social system, ideology, and political propaganda (see Jn 4:3-5). ${ }^{33}$

\section{JeSUS AND Abraham}

The Johannine author compares Jesus and Abraham for rhetorical purposes. Jesus as Messiah/Christ existed before Abraham ("before Abraham was, I am," Jn 8:56-58). Moreover, the author shows not only the presence and the active involvement of Jesus Messiah/Christ as the Word in God's creation (Jn 1:1-3), but also his superiority over the patriarchs, such as Abraham and Jacob, whom the Jews, scribes, and Pharisees venerated (Jn 8:33, 39, 56-58).

The promise that Abraham was not only father of the Jewish nation (Jn $8: 33,37,39,53,56)$ but also the father of "countless nations" ${ }^{34}$ is clearly affirmed in God's covenant with him (Gn 17:4-7). The Johannine author reminds his readers, especially his Jewish readers who were aware of the Genesis covenant, that God had made Abraham the father of all peoples who obeyed God and followed the teaching and instruction of Jesus as Messiah/Christ (Jn 8:31-58). Jesus as Messiah/Christ did not favor one

33 This argument will subsequently be reread for Koreans who face the problem of reconciliation and reunification between the two Koreas (see below).

34 Joachim Jeremias, Jesus's Promise to the Nations (London: SCM, 1958, 1967; Minneapolis: Fortress Press, 1982), 63. 
particular ethnic group, nor did he identify himself with any nation and people on racial and ethnic lines (Jn 18:33-37), unlike the apostle Paul, who explicitly identified himself as Jew or Hebrew (Rm 9:1-5; Phil 3:4-6).

John's gospel further portrays the Jewish religious leaders (and Pilate the Roman governor) as accusing Jesus of claiming kingship over the Jews and replacing Caesar, thus making him a political criminal (Jn 18:33-19:21). But the Johannine author envisions a kingship that would go beyond the confines of Palestine, beyond the immediate readers of his gospel in the regions of Ephesus and Asia Minor, and even beyond the Roman Empire to the rest of the world (ho kosmos, Jn 1:9, 10; 3:16, 17; 4:42; 6:33, 51; 7:4; $9: 5 ; 11: 9 ; 12: 46 ; 13: 1 ; 16: 28 ; 18: 36,37 ; 20: 30-31) .{ }^{35}$

\section{JESUS AND JACOB}

The Johannine author compares Jesus and Jacob in John 4:12. In Genesis 35:10-12 God made a covenant with Jacob that was the continuation of the covenant with Abraham and Isaac, his forefathers. In the covenant God changed his name from Jacob (Heb. yaicob) to Israel (Heb. israel), which literarily means "a person who struggles or wrestles with God" (Gn 32:2232). God promised Jacob that through him would come a nation and a company of nations and kings (Gn 35:11).

Jacob the patriarch and ancestor of the Israelites made the most significant contribution to forming the Jewish nation and its racial identity. But Jacob once settled in Shechem and Bethel, which was located in the region of Samaria in the time of Jesus (Gn 33:18-30; 35:9-15; 1 Kgs 12:2930). Thus, Jacob was the ancestor of the Jews and Samaritans whom his later Jewish descendants despised and detested (Jn 4:9).

The Johannine author consciously compares Jesus to Jacob in the language of the Samaritan woman (Jn 4:12). He traces the movement of Jesus the Messiah/Christ, who walked across the border between Judea and Samaria and passed through Samaria and engaged in conversation with its local residents. This action was symbolically the messianic mission. Jesus followed the footsteps of the Jewish patriarchs and forefathers who had settled and resided in Samaria, and he fulfilled the covenants that God had made with Jacob and Abraham who were the fathers of countless nations.

35 For the audience of John's Gospel see Kruse, John, 21; The Letters of John (Grand Rapids: Eerdmans: Leicester: Apollos, 2000), 27-28; Byrne, Life Abounding, 7. 
Moreover, Jesus challenged the Jews and their religious leaders who looked down upon the Samaritans and undermined their claim of their religious and ethnic privilege and superiority over the Samaritans.

Furthermore, the question, "Are we not right in saying that you are a Samaritan and have a demon?" should be scrutinized through rhetorical lenses. The two different concepts - to be a Samaritan and to have a demon - may have been considered as synonymous by the Jewish religious leaders. In other words, the Samaritans as a whole were also demonpossessed (daimonion). ${ }^{36}$

In this respect the Jewish leaders may have asked Jesus the question in order to trap him. They may have wished to publicize Jesus as demonpossessed in order to condemn him in public and denounce his teachings. They devalued all the signs and miracles that he had performed as driven by demons (Jn 8:1-11, 31-47; 20:30). They placed Jesus in the same category as the Samaritans because he appeared not to have valued Jewish superiority over the Samaritans; instead, he fraternized and intermingled with the Samaritans in Sychar (Jn 4:3-42).

But for the Johannine author, Jesus's action fulfilled his messianic mission and God's covenant with Abraham and Jacob, who were the fathers of other nations as well, not just the Jewish nation (Jn 8:48-58). Jesus as Messiah/Christ breaks through any kind of racial and social boundaries and welcomes all peoples of different ethnic, social, linguistic, and socioeconomic backgrounds with the love and hospitality of God (Jn 4:4-9).

This messianic act, however, posed a critical challenge to his Jewish opponents and provoked them to plot his death (Jn 11:45-53). On the other hand, the act should be a remarkable encouragement for Samaritans and other Gentile peoples who were invited and welcomed into the kingdom/ empire of God/Yahweh, the Creator. This notion will be further explored in the scrutinization of John 4 and 8 through postcolonial lenses in the following section.

36 The Greek word daimonion (demon) occurs six times in John's Gospel (7:20; 8:48, 49, 52; 10:20, 21). For the study of evil spirits in the gospel see André van Oudtshoorn, "Where Have All the Demons Gone?: The Role and Place of the Devil in the Gospel of John," Neotestamentica 51 (2017): 65-82. 


\section{Postcolonial Readings}

An investigation of John 4 and 8 from postcolonial perspectives would help legitimize my argument for the Johannine chapters that contain the author's rhetorical strategy and Jesus's messianic mission and challenge the Jewish hierarchical religious superiority over Gentile nations and against the hegemony of Roman imperialism. In the exercise of this particular biblical hermeneutics, the words "Samaria" and "Judea" and "Samaritans" and "Judeans" (or Jews) are most important and will be the primary focus. ${ }^{37}$ Samaria and Judea were neighboring territories. The boundary lines between these two adjacent territories, whether the lines were drawn for administrative, political, or religious purposes, can be regarded as a significant token or representation of the political, religious, cultural, social, and ideological conflicts for centuries up to Jesus's time.

Israel was split in two in the tenth century BCE (1 Kgs 12:1-33; 2 Chr 10:1-19). The northern kingdom comprised ten of the twelve tribes of Israel and Samaria was its capital (Is 7:9; Amos 3:9; 8:14). The people built their own worship centers in Bethel and Dan and completely cut off their religious ties with Jerusalem (1 Kgs 12:29-33). The northern kingdom was destroyed by Assyria in 720 BCE (2 Kgs 15:29; 17:3-6).

The southern kingdom of Judah consisted of two tribes with Hebron and later Jerusalem as its capital. It was destroyed by Babylon in $586 \mathrm{BCE}(1$ Chr 9:1-3). The two adjoining territories, Samaria and Judea, were socially and religiously disconnected from each other, though they had the same origin and the same ancestors, such as Abraham, Jacob, King David and King Solomon. The Samaritans were considered half-breeds of the Jewish nation (see $1 \mathrm{Kgs}$ 11:26-40).

But under Rome, Samaria and Judea were a single province. Both belonged to the Roman province of Judea. The local residents of the

37 I am aware that Fernando F. Segovia presents the Gospel of John as a postcolonial text and reads it from postcolonial perspectives. Yet he does not thoroughly examine Jesus's messianic journey to Samaria and his messianic engagement with its local people (see Segovia, "Gospel of John," 175-180). But Musa W. Dube offers a postcolonial examination of John 4:1-42 and Jesus's encounter with the Samaritan woman in the Johannine text. She reads the text to decolonize "the perversity of imperialism" in biblical studies and interpretations (Musa W. Dube, "Reading for Decolonization [John 4:1-42]," in Dube and Staley, eds, John and Postcolonialism, 5175, esp. 74). In spite of this, her studies do not focus on Jesus's messianic act of going through to Samaria in John 4:3-9. 
two regions were ruled by a governor appointed by Rome, such as Herod Archelaus (4 BCE to $6 \mathrm{CE}$, cf. Mt 2:22) and Pontius Pilate (26$36 \mathrm{CE}$ ). Technically they were one province under the Roman rule, but administratively, two districts. ${ }^{38}$

\section{Was Jesus a Decolonizer?}

The Jewish people in Palestine continued to claim their ownership of Torah and their religious supremacy over the Samaritans in the time of Jesus. ${ }^{39}$ This is implicitly indicated in Luke's rhetorical description of Jesus, who spoke a parable in which a Samaritan man helped a traveler or sojourner who was beaten and wounded by robbers. On the contrary, two Jewish religious men-Levite and priest—ignored the wounded person and passed him by (Lk 10:29-37). Brendan Byrne claims that the audience/ readers of the parable should "identify with the experience of the wounded traveler." ${ }^{40}$ It would be more likely, from a postcolonial perspective, that Luke shows Jesus deliberately targeting Jewish religious leaders who claimed ownership of the Torah and yet failed to be humane toward people in trouble, especially strangers and outsiders. ${ }^{41}$ They thus failed to follow the teaching of the Torah which is to love God and neighbors (Lk 10:27). They despised Samaritans, who were believed not to have Torah (John 4:9). Yet in the parable it was the good Samaritan who showed love to the injured traveler, as instructed in the Torah (Lk 10:33-35; cf. Lv 19:18; Rm 13:8-10).

In John 8:37-41 the Jews are portrayed as claiming special privilege as descendants of Abraham, who obeyed God. Yet they failed to recognize Jesus as Messiah/Christ whom God sent to them in order to fulfill his covenant with Abraham and Jacob who were the fathers of nations,

38 See Carter, John and Empire, 289-314. Carter makes a remarkable contribution to reading the Gospel of John in relation to the Roman Empire (see Carter, John and Empire, 3-51).

39 The Jews' condemnation of the mixed blood of Samaritans through intermarriage with pagan nations would be included (see Jn 4:9; for laws on ban of interracial marriage see Dt 7:2-15; $1 \mathrm{Kgs} \mathrm{11:1-5;} \mathrm{Jn} \mathrm{4:9).}$

40 Brendan Byrne, The Hospitality of God: A Reading of Luke's Gospel (Collegeville: Liturgical Press, 2000), 101.

41 David E. Garland, Luke: Zondervan Exegetical Commentary on the New Testament (Grand Rapids: Zondervan, 2011), 442; see John T. Carroll, Luke, a Commentary (Louisville: Westminster John Knox Press, 2012), 242. 
including Samaritans and other Gentile peoples. Moreover, they neither understood nor accepted Jesus's prophetic messianic mission, which embraced all nations and all peoples who would become descendants of Abraham by obeying God and believing in Christ who came from God (Jn 8:39-43).

Ironically, it was the Samaritans, whom the Jews despised, who recognized Jesus as Messiah/Christ and believed in him (Jn 4:25, 26, 3942). ${ }^{42}$ They acknowledged Jesus, a Jewish man, who broke through the boundaries that his fellow Jews had drawn against the Samaritans (Jn 4:9). His act of walking through Samaria and encountering and interacting with the Samaritan woman in Sychar demonstrated his strategic intent and messianic mission to decolonize and transcend Jewish superiority over the Samaritans, which was rooted in the Jewish ideological convention and formality (Jn 4:9; 8:48). In this respect Jesus could be seen as a decolonizer who decolonized the Jews' religious and racial elitism. Jesus's action was a messianic and prophetic act.

It is important to note, nonetheless, that in the Gospel of John the Jewish privileges and religious tradition elucidated in the covenant that God made with Abraham and Jacob were not abolished. They were acknowledged by Roman governors such as Pilate (see Jn 18:31, "Pilate said to them, '...judge him/Jesus according to your law"'). Jesus, however, challenged the Jews who claimed to be children of Abraham whom God had made the father of nations yet maintained their hierarchical mentality, racial superiority over the Samaritans, and exclusive attitude toward Gentiles (Jn 8:33-41).

Furthermore, John does not depict Jesus as a decolonizer seeking to overturn the imperial system. Jesus did not attempt to replace it with a new empire/kingdom of God where he was king. It was not part of his messianic mission in the world (Jn 4:43-54; 18:28-19:16).

At the same time, the Johannine author does not depict Jesus as supporting the colonization of Palestine by the Romans. Rome had no final authority over him; Pilate's authority was ultimately "given from above" (Jn 19:11). By this, John was encouraging his readers undergoing persecution not to surrender to the hegemony of Roman imperialism. It should further be noted that, unlike the Synoptic Gospels, John makes no

42 The Greek word christos occurs nineteen times in the Gospel of John: 1:17, 20, 25, 41; $3: 28 ; 4: 25,29 ; 7: 26,27,31,41,42 ; 9: 22 ; 10: 24 ; 11: 27 ; 12: 34 ; 17: 3 ; 20: 31$. 
mention of the narrative in which Jesus expressed his respect to Caesar on the matter of imperial taxation (Mt 22:21; Mk 12:17; Lk 20:24; cf. Rm 13:7). In this regard John could be seen as a decolonizer who forswore loyalty to the emperor who persecuted his Christian brothers and sisters. Against the imperial cult, John calls his readers to worship the only God, the creator, and to believe in Jesus as Messiah and Savior of the world (Jn 1:12; 5:44; $6: 33,99 ; 8: 54 ; 14: 1)$.

\section{Conclusion}

Looking at John 4 and 8 from a rhetorical and postcolonial perspective, we see Jesus the Christ/Messiah who broke through cultural, religious, ethnic, and ideological barriers that separated peoples and nations and treated them equally and welcomed them into the kingdom/empire of God. He refused to submit to the power of Roman imperialism. This was encouraging to the original readers, who were undergoing severe persecutions under the emperor in the last decades of the first century.

These biblical and theological insights can help us confront racial and religious discrimination and to address political and ideological conflicts among peoples. As followers of Jesus the Messiah we are encouraged and challenged to break through and overcome all kinds of boundaries established by people. Jesus's messianic mission was to transcend these boundaries and welcome all people with the hospitality of God (Jn 4:13$14,39-42,46-54 ; 8: 48-58)$.

\section{Application to the Korean Peninsula}

While I was writing this essay, I envisioned Jesus Messiah/Christ walking across the DMZ (De-Militarized Zone), the military divide between North and South Korea, and visiting every corner of North Korea. He interacts and fraternizes with North Koreans, women and men and girls and boys. He talks with them and listens to their stories, just as he intermingled with the Samaritans in John $4 .^{43}$

43 For detailed explanations of the history of North Korea and its Juche ideology see Paul French, North Korea: The Paranoid Peninsula-A Modern History, rev. ed. (London and New York: Zed Books, 2007), 11-230; also Oh-Young Kwon, "1 Corinthians 8:46: An Inter-cultural Reading from the Political Context of the Democratic People's Republic of Korea (North Korea) Today," US-China Foreign Language, 15 (2017): 43-55. 
I visited the DMZ several years ago. On that visit I imagined Jesus seated at the center of a dialogue table. And then he would encourage the delegates of both sides to put aside their ideologies, political agendas, and diplomatic tensions. And they would then talk and share their stories and daily lives as friends of the same nation, the same language, the same cultural and traditional practices, and the same ancestral legacy. This act of Jesus in my imagination would be similar to the way Jesus as Christ/ Messiah interacted with the Samaritans in John 4.

\section{About author}

KWON Oh-Young (Ph.D., University of Divinity) is senior lecturer in New Testament and dean of the Korean Department at Alphacrucis College, Sydney, Australia. 